\title{
NOTE ON CONTRIBUTORS
}

Alex Fleck, B.A. (Waterloo), M.A. (Waterloo), is an English PhD student examining retrogaming hardware and software through a media archaeology and philosophy of technology lens. This research coincides with Fleck's other research into interfaces, FPGA emulation, various histories of computing technology, modding communities, the right to repairability, and game design.

Lasse Hodne is Professor of art history at the Norwegian University of Science and Technology. He has written two books and number of articles on Italian art from different periods, focusing especially on iconography and iconology. Other fields of interest are face perception in portraits, symmetry studies, and fascist aesthetics.

Andreas Helles Pedersen is a PhD student in musicology at Lund University. His research interests span from music historiography and listening practices, over cultural theory and aesthetics, to media philosophy and sound in film. He is currently working on an interdisciplinary project that examines music historical understanding and discourse in a world of streaming and digital music archives.

Zoltán Somhegyi is a Hungarian art historian with a $\mathrm{PhD}$ in aesthetics, currently based in Sharjah, United Arab Emirates and working as Chair of the Department of Fine Arts of the College of Fine Arts and Design at the University of Sharjah, and from September 2020 he will continue as Associate Professor of Art History at the Károli Gáspár University of the Reformed Church in Hungary. He is the Secretary General and Website Editor of the International Association for Aesthetics and member of the Executive Committee of the International Council for Philosophy and Human Sciences. www.zoltansomhegyi.com

Jan Løhmann Stephensen is Associate Professor in the Department of Aesthetics and Culture, Aarhus University. Løhmann Stephensen especially conducts research and writes on human and non-human participation in (post-)creative, cultural, and political processes. He is also co-editor and co-founder of Conjunctions: Transdisciplinary Journal of Cultural Participation. 
Anders Troelsen is Professor at the Aarhus School of Architecture and former Associate Professor in art history at Aarhus University. He has published numerous books and articles concerning art, film, and city planning and within the field of inter-arts. A comprehensive book about pictorial analysis is forthcoming this autumn. His recent publications include "The Silent Conversation of Things: Salient Points in the Still Life Genre” in F. Kjems and A. G. Jensen (eds.), The Silent Life: Illusion \& Reality (2015), "Willumsen, Vitalism and the Light" in J. R. Schelde and L. Pennington (eds.), Wild, Bold, and Late Willumsen (2016), "Deflected Reflections. Contrast, Symmetry and Time in the Video Art of Douglas Gordon” in L. Pennington (ed.), In my shadow. Douglas Gordon (2019), "Sans og samling. Om forholdet mellem maleri og musik" in $K \& K$, nr. 127 (2019), and a forthcoming article on Louise Nevelson (2020).

Jacob Wamberg is Professor of art history at Aarhus University. He works on an evolutionistic theory of the visual arts, syncretically fusing areas such as complexity theory, biosemiotics, philosophy of technology, and posthumanism. His publications include Landscape as World Picture: Tracing Cultural Evolution in Images (2009 [2005]), Totalitarian Art and Modernity (2010, ed. with Mikkel Bolt Rasmussen), Art, Technology and Nature: Renaissance to Postmodernity (2015, ed. with Camilla Skovbjerg Paldam), and The Bloomsbury Handbook of Posthumanism (forthcoming 2020, ed. with Mads Rosendahl Thomsen). 